\title{
The Effect of Macroeconomic Variables on the Stock Market Index of the Tehran Stock Exchange
}

\author{
Mohsen Mehrara ${ }^{1, a}$, Yazdan Gudarzi Farahani ${ }^{2}$, Farzan Faninam ${ }^{3}$, \\ Abbas Rezazadeh Karsalari ${ }^{4}$ \\ ${ }^{1}$ Faculty of Economics, University of Tehran, Tehran, Iran \\ ${ }^{2} \mathrm{Ph}$.D student in Economics, University of Tehran \\ ${ }^{3}$ BA student in Economics, University of Tehran \\ ${ }^{4}$ Department of Management, Tafresh Branch, Islamic Azad University, Tafresh, Iran \\ ammehrara@ut.ac.ir
}

\begin{abstract}
Keywords: Macroeconomic variables, Stock Price Index, Monetary and Fiscal Policy, Vector Autoregressive Model.
\end{abstract}

\begin{abstract}
This paper examines the relationship between stock market index and macroeconomic policies (Fiscal and Monetary) on Iran's economy using quarterly data in the period 1999-2013. This study employed cointegration test and vector autoregressive models (VAR) to examine relationships between the stock market index and the macroeconomic variables. The empirical results reveal that a positive money shock can increase stocks return. According to impulse responses, the government expenditure had a slight impact on stocks return in the short term. But the government expenditure has a positive effect on exchange index in long run. Also the effect of taxes on the stock's price index is negative, so that it reaches its maximum level after the third lag and then alleviates. The GDP shock has positive effect on the stock's price index. Increase in production level leads to increase in earnings and profitability, leading to a positive response from stocks index. Therefore the results showed that the macroeconomic variables such as inflation, exchange rate and GDP have significant effects on Tehran exchange price index. So the hypothesis that the improving economic factors can have a useful role in the booming capital market is confirmed. Also the effect of fiscal policy factors such as tax revenues and government expenditures is more than monetary policy factors on stock returns.
\end{abstract}

\section{Introduction}

The aim of this paper is to investigate the relationship between macroeconomic variables and stock index to find more about the impacts of fiscal and monetary policy and the sensitivity of the stock index. Monetary policy authorities in their effort to maintain low inflation will mainly influence the economy's interest rates.

In the midst of the on-going macroeconomic and financial Market performance, fiscal policy making has been at the forefront. The vast majority of governments around the globe have investigated the claim that whether fiscal and monetary policy influence stock index in order to undertake a significant fiscal impulse to boost economic activity. Moreover, as economic conditions improve the policy focus will shift to the sustainability of fiscal and monetary balances implying that governments will start withdrawing the sizeable fiscal policy stimulus packages and the financial sector support schemes [1,2].

Furthermore, fiscal policy stances can also influence stock market performance. Fiscal policy used in a Keynesian manner can support aggregate demand, booting the economy and potentially driving stock prices higher. In contrast, classical economic theory focuses on the crowding out effects of fiscal policy in the market for loanable funds and of the productive sectors of the economy. Hence, fiscal policy could potentially drive stock prices lower through the crowding out of private sector activity [3].

Given that the links between the real economy and the financial sector could pose risks to economic and financial stability, the first issue is to better understand the feedback loops between government activity and financial and real estate markets [1]. 
Some economists contend, for instance, that monetary policies that result in persistent or highly variable inflation destabilize financial markets [4]. Stock prices are utterly sensitive to economic conditions and also empirical evidence show the association between macroeconomic variables, which influence economic conditions and stock prices.

Good friend [5] argue that, by contrast, asset prices wouldn't respond to specific policy actions under policy rules that maintain a stable price level. Such rules are thought by some to lessen the chance of asset price bubble [6], though other researchers claim that inflation stabilization can raise imbalances that lead to bubbles [7].

Evidence from the Tehran Stock Exchange indicates that the relative stability of the interest rates and other macroeconomic variables have been the most important element to the growth of the stock market. Empirical evidence shows that in the Tehran Stock Exchange faced a number of investors when in actual fact we were close to the slump and the consequences derived from intervene in the stock market by fiscal and monetary policy that not only don't choke off the bubble, but also had adverse implications such as "overshooting". The overshooting hypothesis emphasizes that a contractionary monetary policy (i.e. an increase in the policy interest rate) shock leads to a large initial appreciation both in nominal and real exchange rates followed by subsequent depreciation. However, investor interest rate in the stock market is increasing as a result of subsiding the interest rate and inflation. In this case, consumer price index (Inflation rate) had a positive significant effect, while exchange rate, interest rate and Treasury bill rate had a negative influence on stock market returns. As it turns out, stock prices are influenced positively by industrial production and negatively by the money supply. Beside the point, we find industrial productions to be negatively influenced by the consumer price index and a long term interest rate.

The purpose of this paper is, therefore, to investigate the relationship between stock market index and macroeconomic variables and to obtain policy implications from the results. The paper is organized in the following fashion. Section 2, describe the methodology and empirical study. Final section contains the conclusions.

\section{Methodology and Data}

\subsection{Data}

In this study, the relationships between stock market index and selected macroeconomic variables such as fiscal and monetary policy variables have been examined for the Iran case. Quarterly data covers the period of 1999:01 to 2013:04. To measure the general stock price level, we use the end-of-quarter values Tehran Exchange Price Index (TEPIX), which are obtained from TSE. Selected macroeconomic variables, consistent with the approach of many other studies, are money stock (M1), government expenditure (GOV), tax revenues (TAX), consumer price index (CPI), gross domestic production (GDP) and exchange rate (EXCH), selected from various issues of the quarterly bulletins published by the Central Bank of Iran. All variables are in the logarithm.

\subsection{Unit root test}

Nelson and Plosser [8] argue that almost all macroeconomic time series typically have a unit root. Thus, by taking first differences the null hypothesis of nonstationarity is rejected for most of the variables. Unit root tests are important in examining the stationarity of a time series because nonstationary regressors invalidates many standard empirical results and thus requires special treatment. Granger and Newbold [9] have found by simulation that the F-statistic calculated from the regression involving the nonstationary time-series data does not follow the Standard distribution. This nonstandard distribution has a substantial rightward shift under the null hypothesis of no causality.

Thus the significance of the test is overstated and a spurious result is obtained. The presence of a stochastic trend is determined by testing the presence of unit roots in time series data. Nonstationarity or the presence of a unit root can be tested using the Dickey and Fuller tests [10]. 
The test is the $t$ statistic on $\varphi$ in the following regression:

$$
\Delta Y_{t}=\beta_{0}+\beta_{1} \text {.trend }+\rho Y_{t-1}+\sum_{i=0}^{\infty} \varphi_{i} \Delta y_{t-i}+\varepsilon_{t}
$$

Where $\Delta$ is the first-difference operator, $\varepsilon_{t}$ is a stationary random error.

If a time-series is found to be non-stationary, a filtering mechanism such as the first difference of the variable can be employed to induce stationarity for univariate model estimation. Augmented Dickey-Fuller [10] and Phillips-Perron tests [11] are carried to test the null hypothesis of a unit root in the level and the first difference of the two variables. As Enders [12] indicated, the Augmented Dickey-Fuller (ADF) test assumes the errors to be independent and to have constant variance, while the Phillips-Perron (PP) test allows for fairly mild assumptions about the distribution of errors. Results of both ADF and PP tests for stationarity are reported in Table 1 . The null hypothesis of a unit root cannot be rejected in the level of the variables, but all null hypothesis of a unit root is rejected in the first difference of the variables. The results in Table 1 unanimously confirm that all variables are integrated of order one I(1). The optimal lag in the ADF test is automatically selected based on the Schwarz Info Criterion (SIC) and the bandwidth for the PP test is selected based on the Newey-West estimator [13] using the Bartlett kernel function, and the numeric values are reported in Table 1.

Table 1. Results of unit root test

\begin{tabular}{|c|c|c|}
\hline variable & $\begin{array}{c}\text { ADF t-statistic } \\
\text { (lag length) }\end{array}$ & $\begin{array}{c}\text { PP t-statistic } \\
\text { (bandwidth) }\end{array}$ \\
\hline Ln GDP & -3.30 & -3.26 \\
\hline Ln GOV & -2.66 & -2.93 \\
\hline Ln TAX & -2.52 & -2.15 \\
\hline Ln CPI & -1.26 & -1.54 \\
\hline Ln M1 & -1.94 & -1.95 \\
\hline Ln TEPIX & -0.98 & -0.89 \\
\hline Ln EXCH & -1.50 & 0.55 \\
\hline Critical Value (95\%) & -3.45 & -3.45 \\
\hline
\end{tabular}

\subsection{Cointegration test}

The cointegration test is based in the methodology developed by Johansen [14], and Johansen and Juselius [15]. Johansen's method is to test the restrictions imposed by cointegration on the unrestricted variance autoregressive, VAR, involving the series. The mathematical form of a VAR is

$$
y_{t}=\theta_{1} y_{t-1}+\cdots+\theta_{p} y_{t-p}+\vartheta X_{t}+\varepsilon_{t}
$$

where $y_{t}$ is an $n$-vector of non-stationary $I(1)$ variables, $x_{t}$ is a $d$-vector of deterministic variables, $\theta_{1}, \ldots, \theta_{p}$ and $\vartheta$ are matrices of coefficients to be estimated, and $\varepsilon_{t}$ is a vector of innovations that may be contemporaneously correlated with each other but are uncorrelated with their own lagged values and other right-hand side variables. We can rewrite the VAR as (Eq. (3)):

$$
\Delta_{y_{t}}=\prod_{y_{t}-1}+\sum_{i=0}^{\infty} \Gamma_{i} \Delta_{y_{t}-i}+\beta_{x t}+u_{t}
$$

Where (Eq. (4))

$$
\Pi=\sum A_{i}-I_{t} \text { that } \Gamma_{i}=-\sum A_{j}
$$

Granger's representation theorem asserts that if the coefficient matrix $\mathrm{n}$ has reduced rank $\mathrm{r}<\mathrm{n}$, then there exist $n \times r$ matrices $\alpha$ and $\beta$ each with rank $\mathrm{r}$ such that $\pi=\alpha \beta^{\prime}$ and $\beta$ ' $y_{t}$ is stationary. Here, $r$ is the number of cointegrating relations and each column of $\beta$ is a cointegrating vector. For $n$ endogenous non-stationary variables, there can be from $(0)$ to $(n-1)$ linearly independent, cointegrating relations. 
According to Granger [16], cointegration means that the two non-stationary variables are integrated in the same order with the stationary of residuals. If the two variables are cointegrated, there exists a force that converges into a long-run equilibrium. In other words, if stock market and macroeconomic variables, there is a force of equilibrium that keeps stock market and macroeconomic variables together in the long-run. There are two test methods to identify the presence of a cointegrating relationship between two variables: (a) the Engle-Granger [17] twostage single equation method and (b) the Johansen-Juselius [15] cointegration test. The Johansen method has two separate tests, the trace test and the maximum eigenvalue test. The Engle-Granger method obtains only one single cointegration relationship whereas it is possible to obtain more than one cointegration relationship with the Johansen method. Given this, the Engle-Granger method is Ordinary Least Squares (OLS) based test and the Johansen method is a maximum likelihood based test that requires a large sample. For the Engle-Granger two-stage single-equation method in this study, the Augmented Dickey-Fuller (ADF) test equation includes an intercept but no time trend. The test equations were tested by the method of least squares. The optimal lags are automatically selected for the ADF test based on the Schwarz Info Criterion (SIC). Based on the residual sequence of the ADF test, the null hypotheses of a unit root cannot be rejected for this country in the study, which has proven having one cointegrating relationship between stock market and macroeconomic variables in the country. Numeric values of the results of cointegration test by the Engle-Granger method are not reported in this study due to space limitation.

Cheung and Lai [18] reported that the Johansen approach is more efficient than the EngleGranger method because the maximum likelihood procedure has significantly large and finite sample properties. The Johansen [14], procedure uses two ratio tests: (a) a trace test and (b) a maximum eigenvalue test, to test for a number of cointegration relationships. Both can be used to determine the number of cointegrating vectors present, although they do not always indicate the same number of cointegrating vectors.

While doing the Johansen cointegration test, if there arises a different result between trace statistic and maximum eigenvalue statistic, the result of maximum eigenvalue test is preferred in this study due to the benefit of separate tests on each eigenvalue.

The results of the Johansen cointegration test in Table 2 show that the trace statistics and the maximum eigenvalue statistics are bigger than the critical values for Iran; therefore, the null hypothesis of no cointegration cannot be rejected at the $5 \%$ significance level for Iran.

The results indicate that there is two cointegration relationship between these variables at the 0.05 level, which the trace statistic and the maximum eigenvalue statistic are greater than the critical values, the null hypothesis of no cointegration can be rejected at the 0.05 level. The results indicate the existence of two cointegrating equation between stock market and macroeconomic variables in the Iran.

Table 2. Results of the Johansen cointegration test.

\begin{tabular}{|c|c|c|c|c|c|}
\hline $\begin{array}{c}\text { Null } \\
\text { Hypotheses }\end{array}$ & $\begin{array}{c}\text { Alternative } \\
\text { Hypotheses }\end{array}$ & $\begin{array}{c}\text { Trace } \\
\text { Statistic }\end{array}$ & $\begin{array}{c}\text { Critical Value } \\
(5 \%)\end{array}$ & $\begin{array}{c}\text { Maximum } \\
\text { eigenvalue } \\
\text { statistic }\end{array}$ & $\begin{array}{c}\text { Critical } \\
\text { Value (5\%) }\end{array}$ \\
\hline $\mathrm{H} 0$ & $\mathrm{H} 1$ & & & & \\
\hline $\mathrm{r}=0$ & $\mathrm{r}=1$ & 216.7946 & 125.6154 & 106.3218 & 46.23142 \\
\hline$r \leq 1$ & $\mathrm{r}=2$ & 110.4728 & 95.75366 & 51.25790 & 40.07757 \\
\hline$r \leq 2$ & $\mathrm{r}=3$ & 59.21491 & 69.81889 & 26.68772 & 33.87687 \\
\hline$r \leq 3$ & $\mathrm{r}=4$ & 32.52718 & 47.85613 & 19.73994 & 27.58434 \\
\hline$r \leq 4$ & $\mathrm{r}=5$ & 12.78724 & 29.79707 & 8.015768 & 21.13162 \\
\hline$r \leq 5$ & $\mathrm{r}=6$ & 4.771471 & 15.49471 & 4.006713 & 14.26460 \\
\hline$r \leq 6$ & $\mathrm{r}=7$ & 0.764758 & 3.841466 & 0.764758 & 3.841466 \\
\hline
\end{tabular}

The likelihood ratio tests show that the null hypothesis of absence of cointegrating relation $(\mathrm{r}=0)$ can be rejected at $5 \%$ level of significance. Thus, we can conclude that stock market and macroeconomic variables are cointegrated in the long run. 


\subsection{VAR estimation}

One of the main issues in financial economics is the behavior of stock returns and macroeconomic variables such as output, inflation, exchange rate and the volume of money in the long-term and in the short-term. Economic researchers have consensus view regarding the impact of economic instability on economic activities. The high rate of inflation in subsequent periods is considered as a critical factor in disturbing real financial activities, investment and the economy as a whole. It seems that inflation has not only a decisive role in the development of financial and monetary markets in developing countries but also in developed countries, which they have lower inflation, low and moderate inflation. Therefore, the macroeconomic condition has always been one the main concerns of investors, especially in stock markets. Given that investors have different investment time horizons, studying the relationship between stock returns and macroeconomic variables in different time measures are of particular importance.

The main purpose of this study is to investigate the relationships between stock market index and selected macroeconomic variables in Iran. For this purpose in this study a time series data model with a vector autoregressive model (VAR) and a vector error correction model (VECM) is used.

To study the dynamics of the variables in the model, impulse response functions are applied. Impulse response function (IRF) of a dynamic system is its output when presented with a brief input signal, called an impulse. More generally, an impulse response refers to the reaction of any dynamic system in response to some external change. In other words, impulse response functions are the responses that the variable within the system gives to the impulse caused by errors. These functions determine the effect of one unit of impulse on the current and future value of the endogenous variable as one standard deviation. Figure (1) show the effect of one unit of stochastic shock as one unit of standard deviation from the logarithm of money stock, logarithm of consumer price index, gross domestic product, exchange rate, tax revenues and government expenditure on the return of Tehran stock exchange market.

According to the figure 1, the response of stock return to one unit of impulse from money stock is positive. In other words, stock return increases with a random positive impulse in money stock. This effect is increasing till the fifth period and then it moves with a fix rate which indicates the short term and midterm effect of money stock on stock return. In fact, money stock as the representative of monetary policy has a short term effect on stock return or on real economy. 
Response to Cholesky One S.D. Innovations \pm 2 S.E.

Response of LTEPIX to LTAX

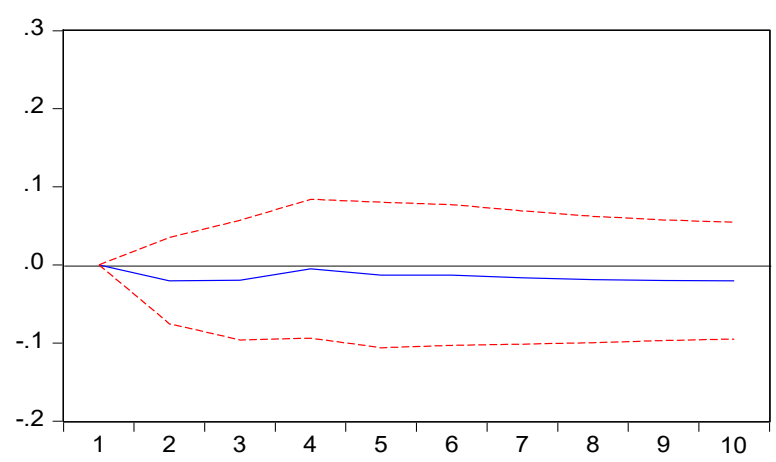

Response of LTEPIX to LM2

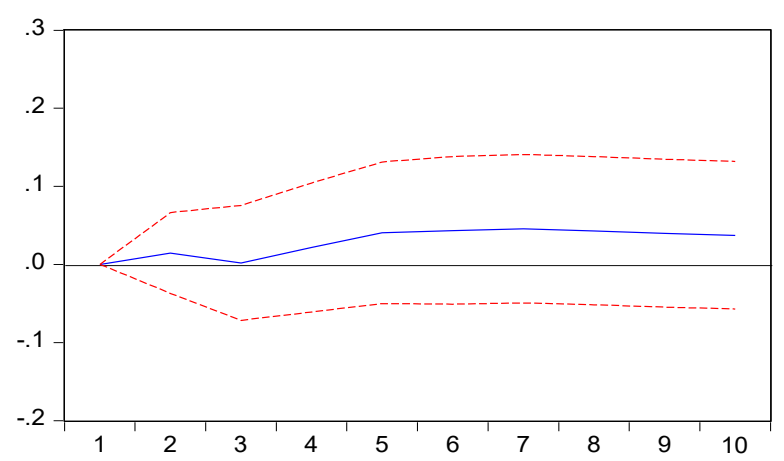

Response of LTEPIX to INFLATION

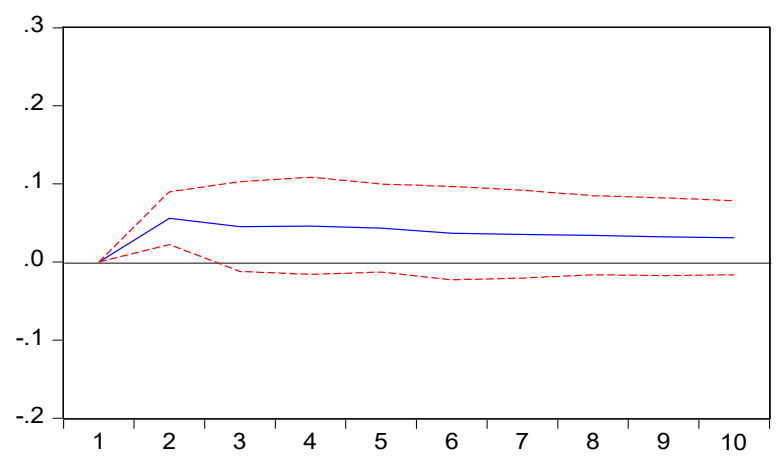

Response of LTEPIX to LGOV

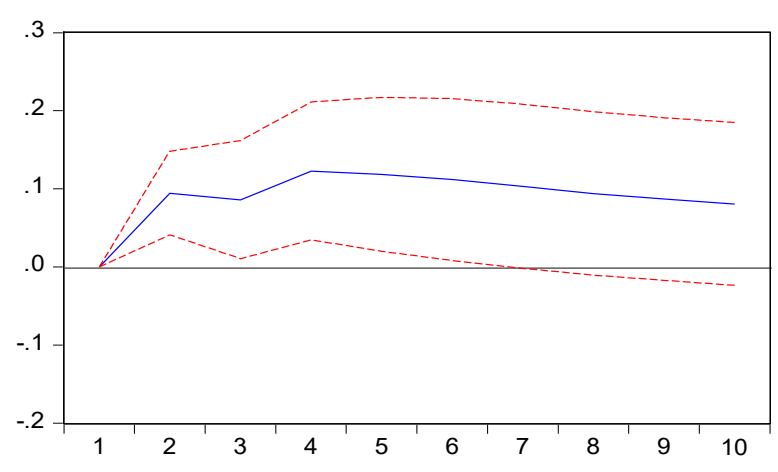

Response of LTEPIX to LGDP

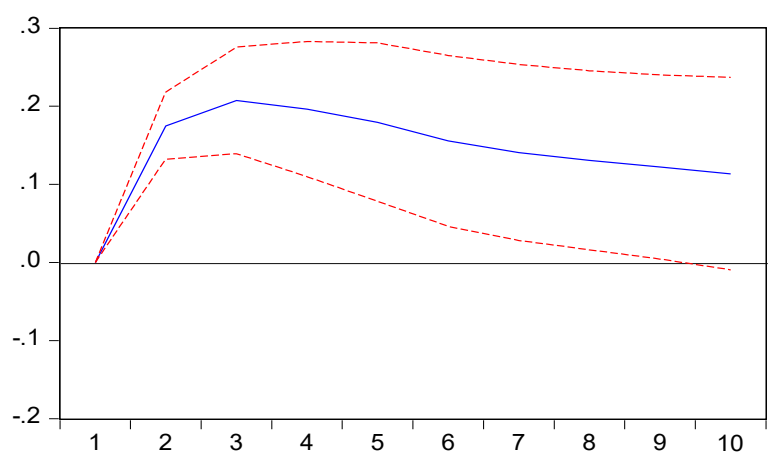

Response of LTEPIX to LEXCH

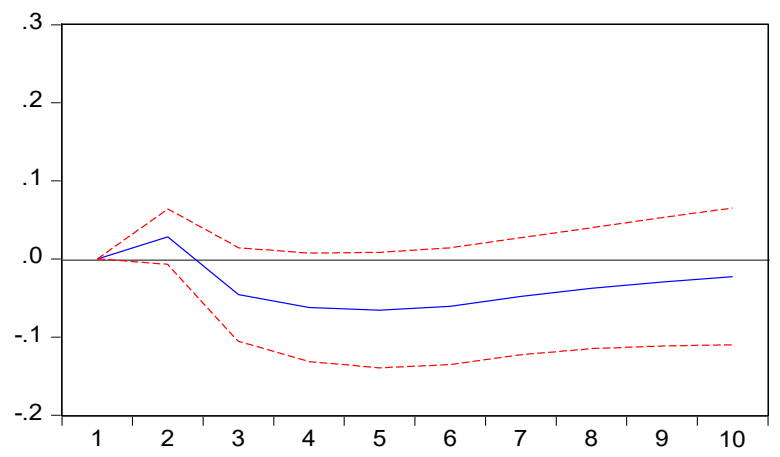

Figure 1. The impulse response of LTEPIX to other variables.

The effect of a random consumer price index impulse on stock return is positive in the short term and this affectivity will be lightly increasing in midterm and till the third period but in the long term with the raise in the consumer price index, firms' profitability will increase less and in turn stock price index will react positively to the changes in consumer price index. Controlling for inflation as one of the main macroeconomic policies was always in the center of attention of economists. Inflation can result in reallocation of resources in favor of property owners and to the expense of employees, increase in uncertainty, shortening the decision making horizon and reduction long term investment.

Exchange rate impulse has a negative effect on stock return index which lasts till the fifth period. After that the positive effects of these impulses will reveal themselves. This reaction is in line with economic theory in which with the increase in the exchange rate in the short term, the cost of supplying raw materials would increase and the firms' profitability would reduce.

Government expenditure random impulse on stock return is small but after the second period this impulse will reveal its positive effect such that in the long term, government expenditure has a positive effect on stock return. Also, the effect of a random tax impulse on stock price index is 
negative and its effect reaches its maximum in the third period and then it starts to alleviate. Probably the main reason for this reaction is the reduction in after tax profit and the discouragement of investors to invest in stock market which reduces the stock price. However, increase in taxes as a contractionary policy would influence production as well which this also works as a negative factor on the negative impact of tax impulses on stock return.

The effect of a positive random gross domestic product impulse on stock return is also positive and it increases stock prices. Increase in production leads to increase in the firms' income flow and their profitability and this causes the positive response of the stock market to the production. In fact, economic growth lead to economic prosperity and the improvement of people's expectation about economic outlook which in turn they increase the investment in real economy and the stock market return.

\section{Conclusion}

The main purpose of this study was to investigate the relationships between stock market index and selected macroeconomic variables in Iran for the period of 1990-2013 based on quarterly data. Price index stock exchange, money stock, consumer price index, GDP, exchange rate, tax revenues and government expenditures are Independent and dependent variables used in this paper. It employs Johansson integration method, Vector Autoregressive (VAR) method and Error correction model (ECM) to investigate this relationship. Results of impulse response functions show that the response of stocks return to a money stock impulse is positive. This implies that a positive money stock shock can increase stocks return. The random impulse of government expenditure on stocks return had a slight impact in short term. But after second lag, the positive impact of impulses reveals which implies that government expenditure has a positive effect on exchange index in long run. Also the effect of the taxes random impulse on the stock's price index is negative, so that it reaches its maximum level after the third lag and then alleviates. The effect of positive random impulse on GDP is positive and therefor GDP has a positive effect on the stock's price index. Increase in production level leads to increase in earnings and profitability and this, results a positive response from stocks index. Therefore the results showed that the macroeconomic variables such as inflation, exchange rate and GDP have significant effects on Tehran exchange price index. So the first hypothesis that the improving economic factors can have a useful role in the booming capital market is confirmed. Also the effect of fiscal policy factors such as tax revenues and government expenditures is more than monetary policy factors on exchange returns.

\section{References}

[1] A. Tagkalakis, Fiscal policy and financial market movements, Journal of Banking and Finance. 35(1) (2011) 231-251.

[2] M. Mehrara, The Relationship between Stock Market and Macroeconomic Variables: a case Study for Iran, Iranian Economic Review. 10(17) (2006) 137-148.

[3] I. Chatziantoniou, D. Duffy, G. Filis, Stock market response to monetary and fiscal policy shocks: Multi-country evidence, Economic Modelling. 30(0) (2013) 754-769.

[4] A. J. Schwartz, Why Financial Stability Depends on Price Stability, Economic Affairs. 15(4) (1995) 21-25.

[5] M. Goodfriend, Interest Rates Policy Should Not React Directly to Asset Prices, in William C. Hunter, George G. Kaufman, and Michael Pomerleano, eds., Asset Price Bubbles: The Implications for Monetary, Regulatory, and International Policies. Cambridge, MA: The MIT Press, 2003, pp. 445-57.

[6] M. Woodford, Interest and prices: Foundations of a theory of monetary policy, Princeton: Princeton University Press, 2003. 
[7] B. Claudio, P. Lowe, Assessing the risk of banking crises, BIS Quarterly Review. (December 2002) 43-54.

[8] C. Nelson; C. Plosser, Trends and random walks in macroeconomic time series: some evidence and implications, Journal of Monetary Economics. 10 (1982) 139-169.

[9] C. Granger, P. Newbold, Spurious regressions in econometrics, J. Econometrics. 2 (1974) 111-120.

[10] D.A. Dickey, W.A. Fuller, Likelihood ratio statistics for autoregressive time series with a unit root, Econometrica. 49 (1981) 1057-1071.

[11] P. Phillips, P. Perron, Testing for a unit root in time series regression, Biometrica. 75 (1988) 335-346.

[12] W. Enders, Applied econometric time series (2nd Ed.), Wiley, New York, 2004.

[13] W.Newey, K.West, Automatic lag selection in covariance matrix estimation, Review of Economic Studies. 61 (1994) 631-653.

[14] S. Johansen, Estimation and hypothesis testing of cointegration vectors in Gaussian vector autoregressive models, Econometrica. 59 (1991) 1551-1580.

[15] S. Johansen, K. Juselius, Maximum likelihood estimation and inference on co-integration with application to the demand for money, Oxford Bulletin of Economics and Statistics. 52 (1990) 169-221.

[16] C.W.J. Granger, Some recent developments in a concept of causality, Journal of Econometrics. 39 (1988) 199-211.

[17] R.F. Engle, C.W.J. Granger, Cointegration and error correction: representation, estimation and testing, Econometrica. 55 (1981) 251-276.

[18] Y.W. Cheung, K.S. Lai, Finite-sample sizes of Johansen's likelihood ratio tests for cointegration, Oxford Bulletin of Economics and Statistics. 55 (1993) 313-328. 